\title{
PENERANGAN BUATAN MENGGUNAKAN PANEL SURYA UNTUK BUDIDAYA BUNGA KRISAN DI DESA BLARANG KECAMATAN TUTUR NONGKOJAJAR KABUPATEN PASURUAN
}

\author{
${ }^{1}$ Taufik Hidayat, ${ }^{2}$ Djoko H. Praswanto, ${ }^{3}$ Rachmadi Setiawan, ${ }^{4}$ Bima Romadhon \\ Parada Dian P. \\ 1,3,4 Institut Teknologi Nasional Malang \\ e-mail ${ }^{1}$ fah_myjeep@lecturer.itn.ac.id \\ 2 djoko@lecturer.itn.ac.id \\ 3 rachmadi@lecturer.itn.ac.id \\ ${ }^{4}$ bimarpdp@lecturer.itn.ac.id
}

\begin{abstract}
Abstrak - Krisan merupakan salah satu bunga terpenting dan memiliki konsumsi tertinggi di dunia. Selain digunakan sebagai bunga hias dan bunga potong, beberapa jenis krisan digunakan sebagai tanaman herbal, dengan sifatnya yang anti mikroba dan anti jamur tanaman krisan dikembangkan sebagai obat tumor dan kanker. Lokasi pertanian krisan di Jawa Timur, salah satunya terletak di Kecamatan Tutur, Kabupaten Pasuruan. Terletak di ketinggian 400 - 1.600 meter di atas permukaan laut (mdpl) budidaya bunga krisan di Kecamatan Tutur dilakukan oleh petani yang tergabung dalam Koperasi Agro Mitra. Dalam program pengabdian kepada masyarakat ini ditemukan beberapa permasalahan baru yang ditemukan dari petani yang telah memanfaatkan teknologi PLTS pada rumah kaca. Penyambungan beban induktif berupa pompa air pada instalasi panel surya yang menggunakan inverter bejenis modified sine wave menyebabkan pompa air dan inverter terbakar karena pengaruh harmonic yang buruk, sehingga akan dilaksanakan penggantian inverter dari jenis modified sine wave menjadi inverter pure sine wave. Hasil kegiatan yang sudah dilakukan yaitu perakitan dan pemasangan inverter pure sine wave pada PLTS kapasitas 1.400 Watt yang digunakan untuk suplai daya listrik pencahayaan tanaman krisan dan proses irigasi pada Mitra. Melakukan pemeriksaan kelayakan instalasi listrik rumah kaca. Selain itu juga dilakukan penyuluhan dan pelatihan cara perawatan panel surya. Diharapkan dengan kegiatan pengabdian kepada masyarakat (abdimas) ini penyediaan tenaga listrik dari energy matahari dapat membantu petani dalam meningkatkan proses budidaya bunga krisan karena energi listrik akan terus tersedia. Penerapan inverter pure sine wave bekerja lebih baik dalam menangani berbagai jenis beban rumah kaca terutama beban induktif. Disamping itu dengan adanya sistem inverter pure sine wave petani tidak perlu khawatir jika sistem PLTS harus digunakan untuk menyalakan pompa air untuk keperluan irigasi.
\end{abstract}

Kata kunci: Krisan, Penerangan Buatan, PLTS, Pure Sine Wave, Rumah Kaca.

\section{PENDAHULUAN}

Bunga Krisan merupakan salah satu tanaman hias populer, dengan produksi bunga terbesar di Indonesia dibandingkan dengan produksi bunga potong pada pasar domestic lainnya selama tahun 2016-2017. Selain itu, Krisan dinilai sebagai komoditas ekspor potensial selama tahun 2017, disusul mawar dan anggrek, dengan volume ekspor sebesar 49,52 ton (Rahayu, et al, 2019).

Krisan merupakan salah satu bunga terpenting dan memiliki konsumsi tertinggi di dunia. Selain digunakan sebagai bunga hias dan bunga potong, beberapa jenis krisan digunakan sebagai tanaman herbal, dengan sifatnya yang anti mikroba dan anti jamur 
(Abdelgaleila et al, 2020), tanaman krisan dikembangkan sebagai obat tumor dan kanker (Tu, Xiang et al, 2021).

Sebagai tanaman yang hidup di iklim subtropis - sedang, bunga krisan yang tumbuh liar saat musim gugur, secara alamiah tumbuh dengan waktu siang hari lebih pendek dibanding dengan malam hari. Untuk menghambat pembungaan awal akibat waktu siang yang singkat (Hoang et al, 2020). Bunga krisan memerlukan penyinaran selama 14-16 jam per hari, pada daerah beriklim tropis seperti Indonesia, dibutuhkan tambahan pencahayaan sekitar 3-4 jam, dengan waktu pencahayaan buatan paling baik antara jam 22.00 hingga 02.00 pagi (Fajrin et al, 2017).

Petani krisan menerapkan pencahayaan buatan menggunakan lampu listrik, sebagai penerangan tambahan rumah kaca pada malam hari, sehingga bunga krisan mekar pada hari-hari tertentu dengan bunga yang besar, kelopak yang indah, sekaligus dapat dijual dengan harga lebih tinggi (Hoang et al, 2020).

Lokasi pertanian krisan di Jawa Timur, salah satunya terletak di Kecamatan Tutur, Kabupaten Pasuruan. Terletak di ketinggian 400 - 1.600 meter di atas permukaan laut (mdpl) dan luas wilayah $94 \mathrm{~km}^{2}$, sebelah barat pegunungan Tengger, daerah ini beriklim sejuk dengan suhu rata-rata 16 - 25 derajat celcius dan curah hujan 3.650 milimeter per tahun. Budidaya bunga krisan di Kecamatan Tutur dilakukan oleh petani yang tergabung dalam Koperasi Agro Mitra yang didirikan pada tahun 2004 yang beranggotakan 80 petani. Dari 12 Desa yang berada di wilayah Kecamatan Tutur baru 7 desa yang tergabung dalam 4 kelompok petani (KP) yang menjadi pusat budidaya bunga krisan, yaitu KP Sekar Sari yang berada Desa Gendro, KP Sekar Alam yang berada desa Tutur, KP Patmasari I yang berada Desa Blarang dan KP Patmasari II yang berada di Desa Wonosari. Salah satu Mitra Abdimas petani bunga krisan yang tergabung dalam KP Patmasari I Bapak M. Yahya Sucipto atau yang akrab dipangil Pak Cip, memiliki lahan budidaya bunga krisan seluas $\pm 4.000 \mathrm{~m}^{2}$. Menurut penuturan Pak Cip, untuk memenuhi permintaan pasar lokal Surabaya dan Malang masih sangat kurang, karena hanya mampu mengirim 700 - 800 ikat bunga krisan atau $7.000-8.000$ tangkai bunga krisan per minggu. Hal ini disebabkan karena kualitas produksi yang masih rendah. Disamping itu, penggunaan listrik dari pasokan PLN dan penggunaan genset saat tejadi pemadaman listrik juga memerlukan biaya operasional yang cukup tinggi (Hayusman et al, 2018).

Permasalahan umum budidaya krisan yang telah dilaksanakan oleh Lauhil Mahfudz Hayusman, dkk, melaporkan permasalahan mitra yaitu biaya operasional yang tinggi akibat penggunaan pencahayaan buatan yang mengandalkan pasokan listrik PLN, penggunaan genset saat terjadi pemadaman listrik, instalasi listrik rumah kaca yang tidak sesuai dengan standar, dan penggunaan energy lampu yang tinggi. Solusi yang diberikan oleh pengabdian sebelumnya telah dilakukan penyediaan tenaga listrik dari energy matahari sehingga dapat membantu petani dalam meningkatkan proses budidaya bunga krisan karena energi listrik akan terus tersedia. Disamping itu dengan adanya sistem otomatisasi petani tidak perlu khawatir jika rumah kaca ditinggal, karena lampu rumah kaca akan menyala dan padam secara otomatis sesuai dengan waktu yang sudah diatur. Setelah dilakukan revitalisasi rumah kaca rugi-rugi daya dan tegangan dapat diminimalisir.

Dalam program pengabdian kepada masyarakat ini ditemukan beberapa permasalahan baru yang ditemukan. Penyambungan beban induktif berupa pompa air pada instalasi panel surya yang menggunakan inverter bejenis modified sine wave menyebabkan pompa air dan inverter terbakar karena pengaruh harmonic yang buruk, 
sehingga akan dilaksanakan penggantian inverter dari jenis modified sine wave menjadi inverter pure sine wave. Instalasi listrik dan jumlah dikakukan pemeriksaan kembali untuk mengurangi resiko kesalahan sistem.

\section{METODE}

Pelaksanaan kegiatan pengabdian kepada masyarakat Kelompok Petani Bunga Krisan di Desa Blarang dan Desa Gendro Kabupaten Pasuruan, dapat dibagi menjadi beberapa tahapan sebagai berikut.

\section{Persiapan}

a) Melakukan kunjungan ke lokasi mitra, yaitu kediaman pak Cip yang tergabung pada kelompok petani Patmasari I, sekaligus sebagai Mitra "Pemanfaatan Teknologi Panel Surya Kelompok Petani Bunga Krisan Di Desa Blarang Dan Desa Gendro Kecamatan Tutur Kabupaten Pasuruan". Tujuannya untuk mendapatkan informasi sebanyak mungkin mengenai permasalahan yang dihadapi mitra.

b) Melakukan wawancara, tujuannya untuk mendapatkan informasi mengenai perkembangan budidaya krisan setelah dilakukan revitalisasi dan pemanfaatan teknologi panel surya pada instalasi rumah kaca.

c) Melakukan pengumpulan data, meliputi pengukuran besarnya daya yang dipakai, pengecekan rugi-rugi (faktordaya, harmonisa, nilai arus), pengecekan kabel, pengecekan peralatan pengaman.

d) Setelah informasi dan data diperoleh secara lengkap, selanjutnya melakukan perencanaan peralatan dan komponen-komponen yang akan digunakan.

\section{Pelaksanaan Kegiatan}

a) Pengadaan alat berdasarkan hasil diskusi dengan mitra diprioritaskan berupa inverter pure sine wave komponen-komponen pendukung lainnya.

\section{Peran Mitra}

Peran mitra yaitu menyiapkan tempat dan memobilisasi anggota kelompok untuk hadir pada kegiatan ini.

\section{HASIL KARYA UTAMA DAN PEMBAHASAN Perakitan dan Pemasangan Peralatan Inverter}

Adanya kegiatan pengabdian masyarakat ini, melanjutkan program kemitraan masyarakat (PKM) "Pemanfaatan Teknologi Panel Surya Kelompok Petani Bunga Krisan Di Desa Blarang Dan Desa Gendro Kecamatan Tutur Kabupaten Pasuruan", yang diharapkan memberikan dampak positif bagi petani bunga krisan, yaitu memberikan solusi terkait dengan permasalahan yang dihadapi petani bunga krisan terkait penyediaan sumber energi alternatif dari panel surya. Pengabdian masyarakat (abdimas) ini diawali dengan koordinasi dengan anggota abdimas yang dilaksanakan pada tanggal 16 Juli 2020 yang bertempat di laboratorium Teknik Elektro ITN Malang. Selanjutnya melakukan koordinasi dengan Mitra pada tanggal 25 Agustus 2020. Kegiatan pertama yang dilakukan yaitu perakitan dan uji coba peralatan yang dilakukan di Workshop Teknik Listrik DIII ITN Malang. Spesifikasi peralatan yang digunakan dalam kegiatan abdimas yaitu:

Inverter pure sine wave untuk penerangan dan irigasi Inverter Pure Sine Wave : 1 unit, 2400 Watt 12Volt/220Volt 
Kegiatan abdimas ini dimulai dengan koordinasi beserta mahasiswa dan anggota abdimas untuk menentukan jadwal kunjungan kepada Mitra abdimas. Setelah koordinasi dilaksanakan, maka kunjungan berikutnya untuk melakukan pemeiksaan teknis dari sistem PLTS yang telah tepasang sebelumnya. Dimulai dengan pemeriksaan kondisi baterai menggunaan AVO meter dengan melihat tegangan baterai apakah normal atau tidak yang ditunjukkan pada Gambar 1. Selain baterai, panel surya beserta instalasi kelistikan rumah kaca diperiksa kembali, apakah ada keausan baik dari sambungan maupun isolasi kabel instalasi, dan beban, pemeriksaan berkaitan dengan keamanan instalasi kelistrikan untuk mengurangi faktor kegagalan yang ditunjukkan pada Gambar 2.

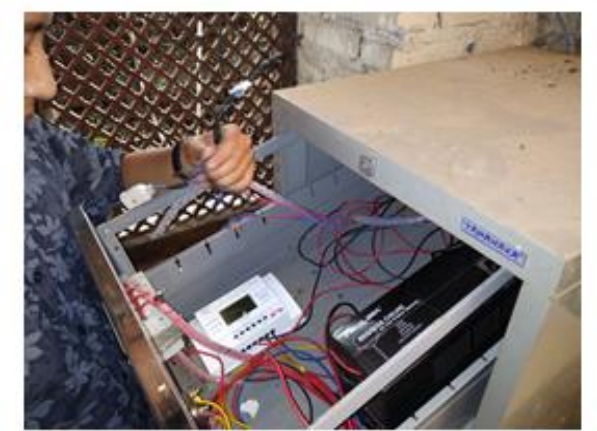

Gambar 1. Pengecekan baterai PLTS
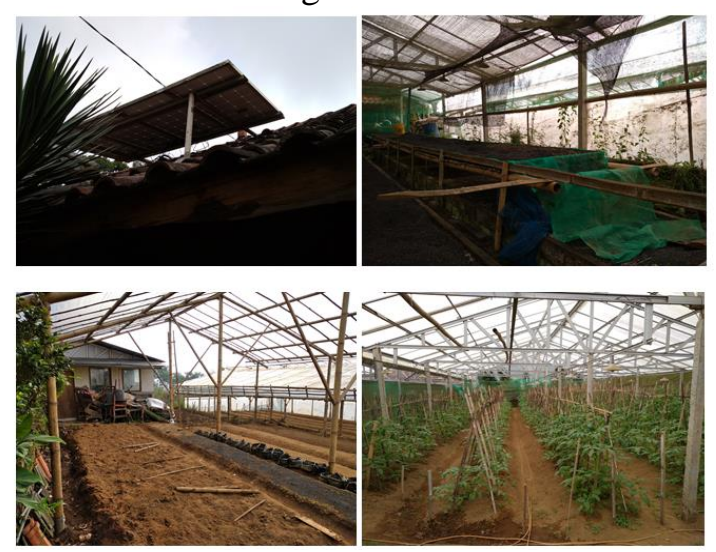

Gambar 2. Pemeriksaan instalasi listrik rumah kaca, lampu dan panel surya pada sistem PLTS

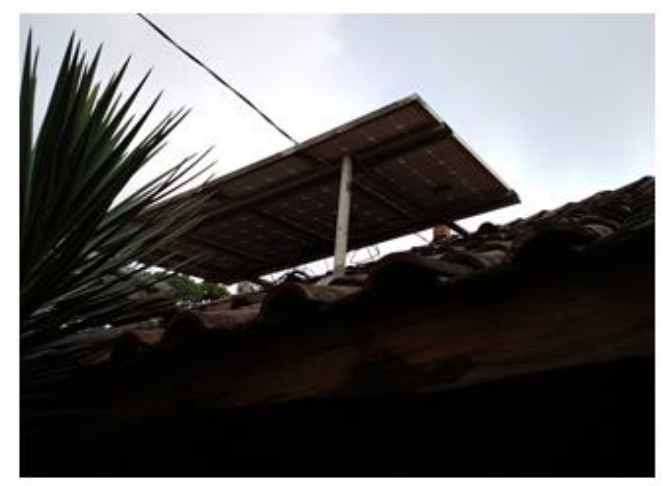

Gambar 3. Pemeriksaan panel surya

Gambar 3 menunujkkan panel surya yang terpasang pada instalasi sebelumnya, dibutuhkan pemeriksaan kembali apakah panel surya masih dapat bekerja dengan baik, pemeriksaan meliputi pengukuran tegangan open circuit dan arus short circuit. 
Pemeriksaan per panel dilakukan untuk menghindari kesalahan akibat adanya panel surya yang sudah aus.

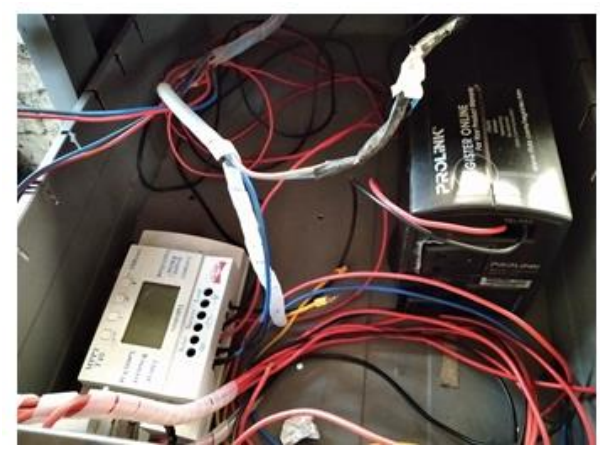

Gambar 4. Pengecekan inverter yang telah terpasang sebelumnya

Pada Gambar 4 menunjukkan sebuah inverter yang digunakan pada sistem PLTS, inverter turut dianalisa dalam pemeriksaan ini, dengan mengukur arus beban dan hamonik dari inverter. Hasil pemeriksaan menunjukkan adanya gelombang harmonic yang timbul sehingga mengakibatkan pompa air dan inverter pada sistem PLTS terbakar.

Pembuatan inverter pure sine wave dimulai dengan proses pembuatan papan PCB yang ditunjukkan pada Gambar 5, kemudian dilanjutkan dengan pemasangan komponen dan menguji inverter per sistem untuk menganalisa apakah sistem normal dan tidak mengalami kegagalan yang ditunjukkan pada Gambar 6. Gambar 7 dan 8 menunjukkan perakitan inverter kedalam casing dan dilakukan pengujian sebelum dilakukan instalasi pada Gambar 9.

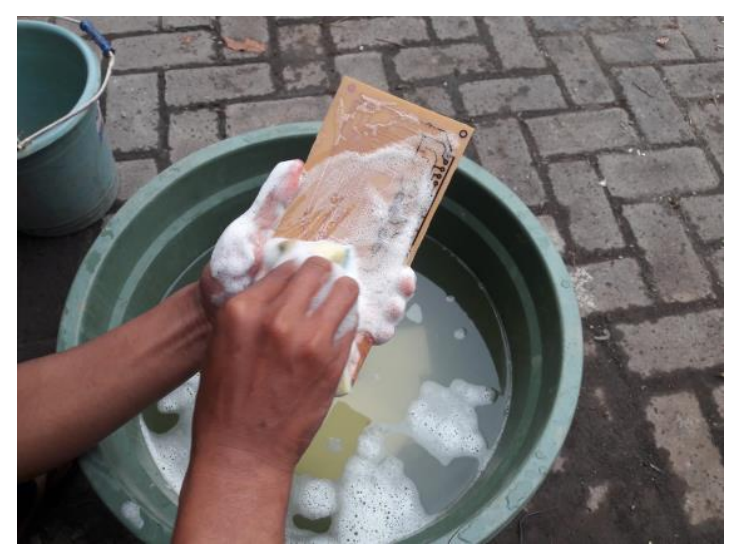

Gambar 5. Pembuatan PCB Inverter

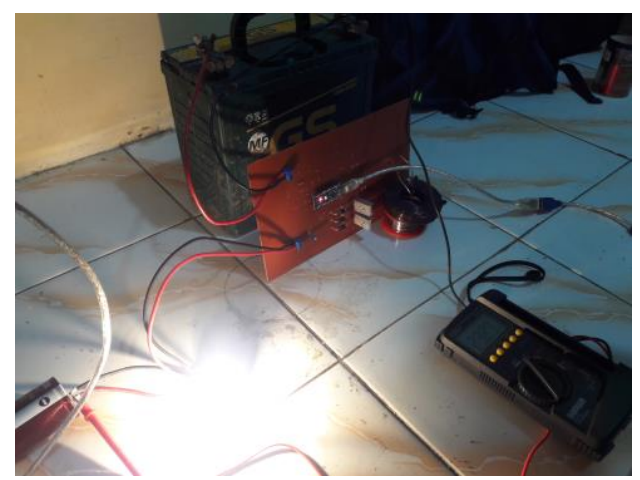

Gambar 6. Pemasangan komponen dan pengujian inverter 


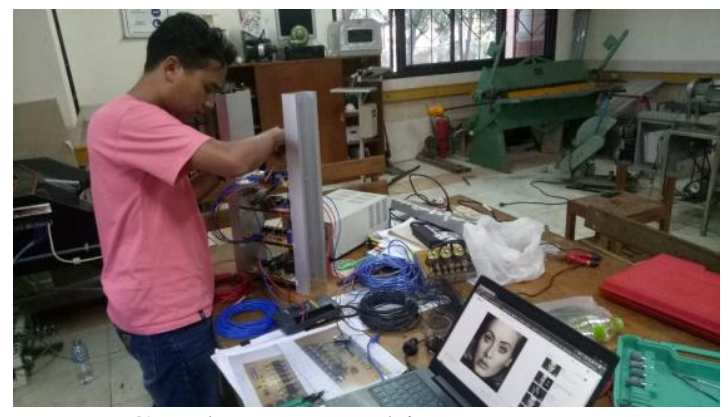

Gambar 7. Perakitan inverter

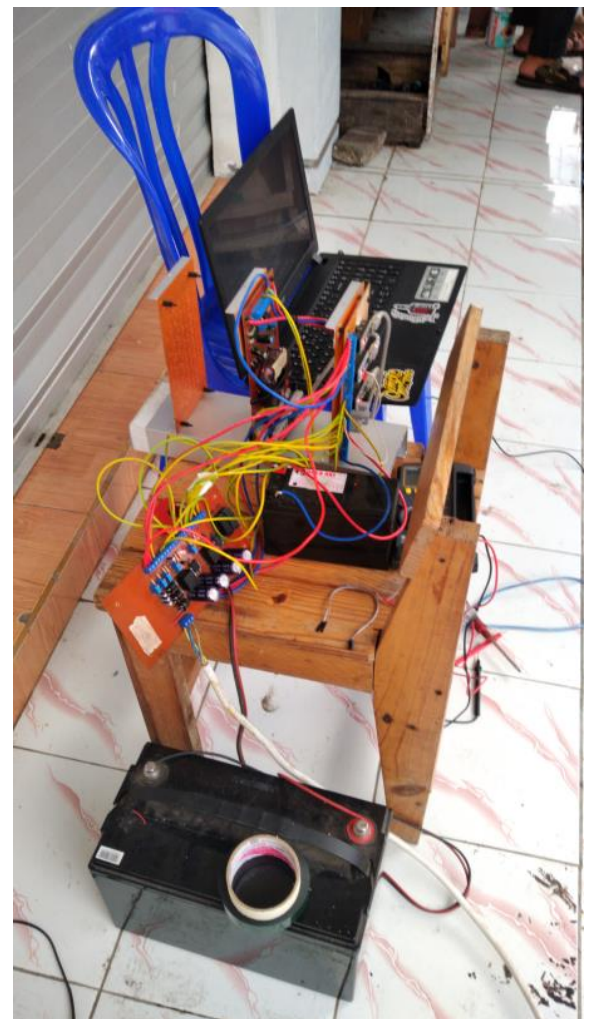

Gambar 8. Pengujian inverter

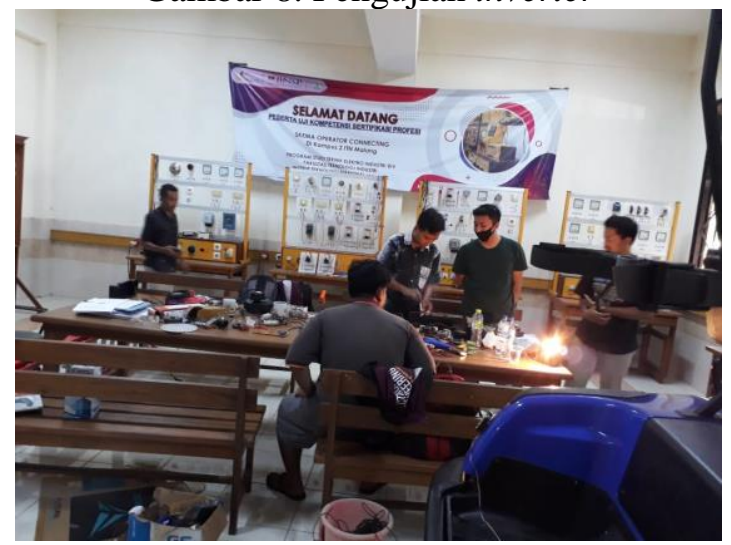

Gambar 9. Pemasangan inverter

Uji coba dilakukan dengan memberikan beban berupa, beban pompa air 250 Watt dan lampu rumah kaca 1200 Watt, dan hasilnya kedua jenis beban tersebut dapat bekerja dengan baik. 


\section{KESIMPULAN}

Kegiatan Program Pengabdian Masyarakat yang dilakukan di Desa Blarang Kecamatan Tutur Kabupaten Pasuruan Jawa Timur berupa penerapan teknologi Panel Surya untuk petani Bunga krisan dapat terlaksana dengan baik. Penyediaan tenaga listrik dari energy matahari dapat membantu petani dalam meningkatkan proses budidaya bunga krisan karena energi listrik akan terus tersedia. Penerapan inverter pure sine wave bekerja lebih baik dalam menangani berbagai jenis beban rumah kaca terutama beban induktif. Disamping itu dengan adanya sistem inverter pure sine wave petani tidak perlu khawatir jika sistem PLTS harus digunakan untuk menyalakan pompa air untuk keperluan irigasi.

\section{UCAPAN TERIMA KASIH}

Terima kasih disampaikan kepada Lembaga Penelitian dan Pengabdian Masyarakat Institut Teknologi Nasional Malang yang tel ah membiayai kegiatan Pengabdian Masyarakat Tahun Anggaran 2020, serta pihak mitra, mahasiswa dan anggota pengabdian masyarakat yang turut serta dalam menyelesaikan kegiatan ini.

\section{DAFTAR PUSTAKA}

E S Rahayu, N Setyowati, I Khomah. (2019). The effects of seasons on chrysanthemum flower (Chrysanthemum indicum) production in Sleman Regency, Yogyakarta, Indonesia. The 4th International Conference on Climate Change 2019 (The 4th ICCC 2019). IOP Conf. Series: Earth and Environmental Science 423 (2020) 012053. Page 1-7.

S.A.M. Abdelgaleila, M.M.G. Saada, N.R. Arieftab, Y. Shionob. (2020). Antimicrobial and phytotoxic activities of secondary metabolites from Haplophyllum tuberculatum and Chrysanthemum coronarium. Elsevier. South African Journal of Botany 128 (2020). Page 35-41.

Xiang Tu, He Bin Wang, Qun Huang, Yi Cai, Yuan Ping Deng, Zhe Yong, Quan Hu, Jian Feng, James B. Jordan, Sen Zhong. (2021). Screening Study on the AntiAngiogenic Effects of Traditional Chinese Medicine - Part II: Wild Chrysanthemum. Ivyspring International Publisher, Journal of Cancer 2021, Vol. 12. Page 124-133.

Thi Thu Linh Hoang, Thi Gam Do, Van Thao Nguyen, Hoai Chau Nguyen, Hong Khoi Phan. (2020). Environmental Impacts of Photoluminescence and Light-Emitting Diode (LED) Lighting Technologies in Horticulture: Case Study on Compact Fluorescent Lamp (CFL) and LED Lights for "Night Break" of Chrysanthemum Cultivation. Sustainability 2020, 12, 7969; doi:10.3390/su12197969. Page 1-9.

N Fajrin, I Taufik, N Ismail, L Kamelia, M A Ramdhani. (2017). On the Design of Watering and Lighting Control Systems for Chrysanthemum Cultivation in Greenhouse Based on Internet of Things.The 2nd Annual Applied Science and Engineering Conference (AASEC 2017). Series: Materials Science and Engineering 288 (2017). Page 1-6.

Thi Thu Linh Hoang, Thi Gam Do, Van Thao Nguyen, Hoai Chau Nguyen, Hong Khoi Phan. (2020). Environmental Impacts of Photoluminescence and Light-Emitting Diode (LED) Lighting Technologies in Horticulture: Case Study on Compact Fluorescent Lamp (CFL) and LED Lights for "Night Break" of Chrysanthemum Cultivation. Sustainability 2020, 12, 7969; doi:10.3390/su12197969. www.mdpi.com/journal/sustainability. Page 1-9. 


\section{JASTEN}

Lauhil Mahfudz Hayusman, Asroful Anam, Taufik Hidayat. (2018). Pemanfaatan Teknologi Panel Surya Kelompok Petani Bunga Krisan Di Desa Blarang Dan Desa Gendro Kecamatan Tutur Kabupaten Pasuruan. Jurnal Aplikasi Dan Inovasi Ipteks SOLIDITAS Volume 1 Nomor 2, Oktober Tahun 2018. Page 59-67. 